Int.J. Hum. Soc. Dev. Res.

ISSN(P):2521-1439; ISSN(E):2523-4331

Volume 4, Number 2, 2020. 7-22

DOI: $10.30546 / 2523-4331.2020 .4 .2 .7$

\title{
STATE RESPONSIBILITY FOR HUMAN RIGHTS PROTECTION DURING THE COVID-19 PANDEMIC
}

\section{Murteza HASANOGLU,}

The Academy of Public Administration under the President of

the Republic of Azerbaijan, Baku, Azerbaijan

\section{Sevinj SHENER,}

Senior Human Rights Officer, Baku, Azerbaijan

(C) The Author(s) 2020

\section{ABSTRACT}

International experience suggests that public emergencies, including natural disasters, armed conflicts, pandemics and etc. pose a heightened threat of mass and systematic human rights violations. The random outbreak of the COVID-19 pandemic once again justified the necessity of the responsibility of states to ensure the right to health of citizens and those, under their legal jurisdiction for residing temporarily or permanently as well as the right to protect. In this paper, we address the issue of state obligations during a state of emergency, including infectious disease outbreak. We contend that there is a pressing need to clarify the rights and responsibilities of States, especially in terms of fulfillment of international obligations as well as preventing discrimination against migrants, noncitizens and homeless persons during the emergencies.

International law bound States to take fiduciary responsibility in terms of trustful citizen and state relationships; in this paper, we address the international law norms and human rights-based approaches to those principles and situations of how states caused to law violations during emergency. Preventive measures for COVID-19 that is unfortunately associated with some breaches of human rights, demonstrated that almost all states were in helpless situation in treatment and preventing this communicable disease. In this article, we will study different human rights under the umbrella of the state responsibility during the pandemic.

C2020.All rights reserved

\section{ARTICLE HISTORY}

Received: 03/06/2020

Accepted:17/09/2020

Published online:30/10/2020

\section{KEYWORDS}

State responsibility, human rights, protection, international law, COVID-19 pandemic 


\section{Introduction}

In this descriptive paper we argue that under the international law, states have an obligation to ensure realization of human rights and freedoms during emergencies amid the precautionary measures. During national crises, states may suspend many human rights protections in order to safeguard national security. However, in this paper we show that even if states halt realization of some rights and fundamental freedoms, such restrictions must not violate peremptory norms, such as the prohibition against torture and prolonged arbitrary detention. We consider that a state of emergency in the context of a pandemic has important impacts on the human rights guaranteed, i.e. measures to prohibit gatherings in public spaces, freedom of peaceful assembly, access to information, right to due process, prohibition of discrimination; consequently, we must accept that a blanket ban on international or inter-city travel could conflict with freedom of movement, self-isolation and forcible quarantines could impinge upon guarantees to the right to liberty and delays of court proceedings could violate the right to be tried within a reasonable time.

During the public health emergencies, states exercise intelligent technology to track the people and collect their personal data, i.e. South Korea and Israel were succeeded in that, whereas others failed and facilitated only infringement of the rights proclaimed in their own legislation. To apply tracking method is good, but not sufficiently. In this article, we claim that online judiciary processes have its own advantages and disadvantages. Of course, it is very useful in tracking the records of severe disease of a patient, or in preventing any accidents, causing injury to an individual. However, all preventive measures taken to response any infectious disease must be temporary. The situation of a disease control and rate of outbreak is changeable and does significantly pose to risks to the duration of violations of the rights and freedoms.

The results revealed that according to the CESCR General Comment 14, para 12 (b) acknowledged that accessibility to information is a key aspect of the accessibility to healthcare. When the legal basis of the state responsibility is analyzed, it has been determined that vast majority of regional and international human rights instruments, for example, the Vienna Declaration and Program of Action, adopted in 1993, expressly stated the significance of the fact that all human rights are interrelated and indivisible and that, state must fulfill them fairly and equally. 
Even so, the full and precise definition of the right to health at the international level for the first time was proclaimed in the 1946 Constitution of the WHO. In addition, indirectly the accomplishment of full freedom from discrimination and stigmatization is defined by the CESCR in a way that all should access to high quality of physical and mental health. The Siracusa Principles oblige governments to take necessary, proportionate and lawful measures.

In every society, during emergencies it is the first, population always become a primary object for any adverse human rights effects, be it an epidemic rapidly becoming a global health emergency, be it a natural disaster or be it an armed conflict, depending on the scale of atrocities. However, according to international law, a State takes an obligation to protect all persons, including citizens, aliens, migrants, persons, who seek for refuge, internally displaced persons, in other words, all, irrespective of the protected grounds falling within his legal jurisdiction. Thus, the fiduciary principle of the State obliges him to ensure equal freedom to his subjects as a sovereign power.

Throughout the history, when emergency situations have had associated with grave wrongdoings in terms of protection and promotion of human rights, sometimes, measures addressing to restore the public health or a human being turned to an unprecedented human catastrophe resulting with mess of law violations. It was always a matter of urgency and proportionate in the light of preventative, protective and precautionary measures undertaken by the state.

International human rights law enables States to derogate from some of their obligations in the context of the public emergencies in the name of their safety and public health (Hartman, 1985: 89). For example, the cornerstones of international human rights law- two international covenants on civil and political rights and economic, social and cultural rights stipulate that

"[i]n time of public emergency which threatens the life of the nation and the existence ..., the States...may derogate from their obligations..." (ICCPR, 1966, Art. 4).

The significance of this criteria has also been emphasized similarly in the European Convention on Human Rights, Art. 15 on derogation in time of emergency, at the regional level (ECHR, 1940, Art.15). 
Nevertheless, governments should not discriminate against the protected grounds whilst taking similar measures, which also has been enshrined under the same Article of this international document. Today, we see what is going on around in order to prevent the spread of this contagious infection from the reports about massive human rights violations, including violations of the freedom from torture and discrimination, freedom of thought and speech, freedom of movement, freedom of privacy of the outstanding international and regional human rights organizations such as Amnesty International, Human Rights Watch (HRW) and World Health Organization (WHO) and ombudspersons.

Currently, the ongoing coronavirus COVID-19, along with its novel type, which also known as (2019-nCOV) and negatively affecting the human lives by increasing the death toll in every state are spreading throughout the world. Surely, now the global world becomes to better understand that it has to align in order to avoid more deaths and severe complications in the future, that is, all states should support each-other, economically and medically, if deemed necessary, to share experiences, but not always, as experiences can be very specific to every country's profile. In 2003, when Severe Acute Respiratory Syndrome (SARS), has emerged in China, in total, 8,098 cases of SARS were recorded in 26 countries, with 774 documented deaths (hospital staff were most affected) as well as travel, tourism, trade and production mostly in Asian countries and Canada in the West have been seriously affected and according to estimates of the WHO, the outbreak costed US $\$ 12.3$ billion (WHO SARS Report, 2003).

Nevertheless, it must be resolutely noted that with a view not to breach any fundamental right under the shadow of fighting against emergency circumstances is absolutely prohibited under the general principles of international law, states must give justifications for any taken measures, their duration, and explanations for the reasons.

\section{Research Purposes}

This study aims to determine the state responsibility towards the protection of persons under its jurisdiction by respecting the universally recognized international human rights principles, including the right to non-discrimination and through the effective realization of fundamental rights and freedoms. 


\section{Research Methods}

This research will describe the relationship between the State and all human beings irrespective of the protected grounds such as race, color, religion, language, age, gender and others under the sovereign jurisdiction. The samples given in this study was a result of analysis online newspapers, internet resources, reports and statements prepared by international human rights organizations, including the Human Rights Watch.

The national state programs, policies, along with international legal documents have been also reviewed. The data collection tool used by the authors is based purely on self-evaluation of the collected materials and analytical thinking. Data analysis was done also on the basis of the surrounding people's opinions.

\section{Legal basis of the State responsibility for Good administration}

Good Governance is not only an existence of the rule of law, checks and balances, but also prevention of human rights violations in a peace and war times. Legal basis for a broad responsibility to protect all rights and freedoms of human beings by any State is based on the principle of indivisibility of human rights (Shenin, 2002: 27/Azeri version). In 1993, the normative framework of the World Conference on Human Rights, the Vienna Declaration and Program of Action acknowledged that...

"All human rights are universal, indivisible and interdependent and interrelated. The international community must treat human rights globally in a fair and equal manner, on the same footing, and with the same emphasis. While the significance of national and regional particularities, and various historical, cultural and religious backgrounds must be borne, it is the duty of States, regardless of their political, economic and cultural systems, to promote and protect all human rights and fundamental freedoms" (Vienna Declaration and Program of Action, 1993: para.5)

Also, the full significance of the right to health at the international level was firstly expressly articulated in the 1946 Constitution of the WHO, which stated in its preamble part that... 
"a state of complete physical, mental and social well-being and not merely the absence of disease or infirmity" (WHO Constitution, 1946 : para.1)

and under the International Covenant on Economic, Social and Cultural Rights signed by majority of States:

"...everyone is entitled to highest attainable standard of physical and mental health" and ...States are bound to take all necessary actions to prevent, treat and control the epidemic, endemic, occupational and other diseases" (ICESCR, 1966, Art. 12).

The United Nations Committee on Economic, Social and Cultural Rights has stated that the right to health directly interrelated to other rights, stated in the International Bill of Human Rights, including the right to life, food, prohibition against torture, non-discrimination, equality, privacy, access to information, to housing, to work, to education, human dignity, freedom of association, assembly and movement.

The right to health should be accessible and affordable to everyone without any discrimination. While ensuring this right medical ethics and culture should be respected, and everyone should be treated equally during the medical examination, treatment and rehabilitation processes through appropriate and quality. According to the Siracusa Principles, (Siracusa Principles, 1984: para.15) adopted in 1984 by the UN Human Rights Committee in its General Comments on state of emergency (CCPR GC No. 29, 2001: Article 4) and freedom of movement provide that governments may restrict human rights for reasons for public health or national emergency. However, the noted Principles also specifically state that all measures for such a restriction of the rights and freedoms of human beings should be lawful, proportionate and necessary and acknowledged that the measures in response to the infection should be provided and carried out in accordance with the law, directed towards legitimate objective of general interest, strictly necessary in a democratic society to achieve the objective, be neither arbitrary nor discriminative in application, of limited duration and respectful of human dignity and etc. (CCPR GC No. 29, 2001: Limitation clauses)

During fulfilling the obligations, all states must obey the binding International Health Regulations, adopted by WHO in 2005, to prevent and manage the public health risks of diseases (WHO International Health Regulations, 2005) 
2. Human rights and Freedoms in the light of Good governance

It is not possible to imagine good governance without proper and full realization of human rights. They are interlinked and indivisible. In order to achieve good governance all governments must activate all human-rights based mechanisms.

Good governance necessitated rule of law, legitimacy, political empowerment of people, mutual trust-based state-citizen relations, private and public partnerships, free monopoly environment, checks and balances, transparency, responsibility, accountability and participation and this list of course, is not an exhaustive. Governments adopt human rights-based programs, policies and legislative framework and other measures.

\subsection{Principle of Non-Discrimination}

As already we noted that almost all international human rights instruments provide that what measures taken or monitoring carried out, it should be based on the prohibition of discrimination and respect for human dignity. Prohibition of discrimination is a fundamental right that is required in realization of almost all human rights and freedoms, including the right to health. Everyone should be free and quality access to medical examination and treatment without being subjected to any discrimination based on race, religion, nationality, health state, gender, age, origin and other prohibited grounds.

As a latest, 16 March 2020, the UN human rights experts acknowledged " ...emergency declarations based on the Covid-19 outbreak should not be used as a basis to target particular groups, minorities, or individuals. It should not function as a cover for repressive action under the guise of protecting health... and should not be used simply to quash dissent" (UN COVID-19 Statement, 20 march, 2020).

The States may derogate from non-peremptory human rights norms, such as right to movement, peaceful assembly, freedom of expression if those rights pose serious risk to the public health and security. However, they may never derogate from jus cogens norms of international law, namely the prohibition of torture, slavery and servitude, right to legality in the field of criminal law, the recognition of everyone as a person before the law, prohibition of imprisonment because of inability to fulfill the contractual obligation (ICCPR, 1966, Article 4), so, States must not exercise discriminative measures in any circumstances (ICCPR, 1966, Article 4). 
In contrast, various governments are still forgetting about their international obligations. For example, according to the Amnesty International, people with Asian appearance have been discriminated against in various countries, like South Korea, France, US and others. Muslims, who have already been stigmatizing in India by the majority of Hindus for many years, after the COVID, this stigmatization and discrimination on the ground of religion became more and more unbearable (Human Rights Watch Report, 2020). The corona time is a challenging for all peoples and communities as anxiety about a disease can lead to social stigma towards society at large. Stigma can occur when a person of a particular nationality or origin was a nearby of the one who had an infection or suspected or travelled to the place, where contagious infections is at dangerous level or in contrary released from quarantine.

First, so-called hate-speech or action of discriminative nature has been made by the US President, D. Trump in one of his speeches when he warned the public calling the infection "China virus" or "Wuhan virus" (Perrigo, 2020). In addition, not always only patients can be discriminated against, some others, who are faced with discrimination are also health professionals and emergency responders, travelers, and persons of Asian descent. However, International Labor Organization compels states to take care of health professionals by ensuring their right to health and preventing occupational diseases through providing them with necessary protective equipment and information (ILO Convention No. 161, 1985, Art. 5). For example, in US, the three caregivers in one of the NYC hospitals were forced to wear trash bags due to lack of medical protective gears and all three have tested coronavirus positive (Fottrell, 2020). It shows that the US has not appropriate emergency preparedness to any unprecedented situations. In contrast, despite fact that in UK people are stigmatized on the ground of spreading the infection, the Commonwealth counter-terrorism police carried out investigation over the allegations against British Muslim population for spreading the virus (Nazia, 2020). The similar hatred and discriminative acts against hundreds of Muslims, have emerged in Sri-Lanka, the government distributed assistance allocated for the poor. It is not distributed not an equal manner and many Muslim poor families were protested to such inequality (Ortega, 2020). Also, Muslims were faced with disrespect to their religion in terms of burial ceremonies.

The government of Sri Lanka implement a new policy, according to which the persons, infected with COVID-19 and died should be subjected to cremation instead of burial (HRW, 2020) which contradicted to Islamic traditions, Muslims must be buried. This mandatory cremation policy of SriLanka is contrary to the requirements of WHO guidance on "Infection Prevention 
and Control for the safe management of a dead body in the context of COVID-19" (WHO Interim Guidance, 2020) and have been criticized by the UN special rapporteurs as a violation of freedom of religion.

During a pandemic, the governments must also protect persons held in detention settings, including prisons, immigration detention centers and residential institutions for people with disabilities and nursing facilities for older persons taking into account that they are members of the vulnerable groups.

In general, persons deprived of their liberty are always at the high risk to be infected due to overcrowding and insanitary and poor hygiene detention conditions. These people were already limited in several rights and freedoms in compare to others at large. State has an obligation to ensure medical care for persons deprived of their liberty, including refugees, undocumented migrants, asylum seekers and their equal access to preventive, palliative and curative health care. Thus, inmates must be treated favorable as much as of others in terms of protection of public health because they are also members of our society and one day, after serving their sentence they will integrate to the society as well. Persons in detention settings are also entitled to get quality and regular medical service either in peace or war time on an equal manner and with dignity as it provided in the UN Subcommittee on Prevention of Torture advice on COVID-19 addressed to national preventive mechanisms (NPM) of States UNCAT Advice, 2020). According to the Advice, the NPMs of all governments must fulfil the principles of "do not harm" and "equivalence of care" while treating persons under custody. In US jails, for example, the government are failed to provide with adequate medical care of the increased number of persons in prisons, locked up just because they cannot pay their bails.

Persons in residential institutions are also very marginalized. They, very often, suffer from various diseases and have weak psychological state and easily prone to depressions. When the government won't care about them in such a challenging time, such people will feel themselves in a helpless situation. This approach belongs also to refugees, asylum seekers and persons experiencing homelessness as well as they have not adequate access to water and hygiene where they live.

Thus, bearing in mind that non-discrimination principle is a fundamental right and interlinked to other rights and that it is not possible to be fully realized without ensuring the rest, all states must be held accountable to fulfil their human rights-based policy with dignity and on an equal basis. 


\subsection{Access to Information vs. Legality to Tracking}

Freedom of information is also one of the cornerstones of all rights and freedoms and is fundamental and intrinsic right, protected by all international human rights treaty (ICCPR, 1966, Art. 19; ACHR, Art. 13). Articles 19 of the UDHR states that

"Everyone has the right to freedom of opinion and expression; this right includes freedom to hold opinions without interference and to seek, receive and impart information and ideas through any media and regardless of frontiers" (UDHR, 1948 and ICCPR, 1966, Art.19).

Moreover, under the international law, the State is obliged to ensure the people to access to accurate and frequent information during emergency time (OHCHR COVID Statement, 19 march, 2020). In 2011, as a result of significant development of this right, the UN Human Rights Committee in its Comments on Article 19, acknowledged that Article 19 covers a general right of access to information held by public officials. But, according to the precedent law, as it appeared in Segerstedt-Wiberg v Sweden case, the Court held that when a State refuses to access to information and has a legitimate fear to disseminate information, due to the national security and counter terrorism, there is no violation of Article 8 of the European Court of Human Rights (Segerstedt-Wiberg v Sweden, 2006: VII).

However, it does not mean that a State may derogate from fulfillment of this right in terms of security of the public health because a person has also the right to be informed about what is going around him or about threats posed to his/her health. During the measures taken to in response to the COVID-19 outbreak, Ethiopia applied a blanket ban on telephone and internet service in a particular region of the country (Human Rights Watch, 2020).

In the United States, Turkmenistan and in some others also applied such bans by concealing the accurate information from the public as provided in the HRW report. Several states shutdown or weaken the internet to prevent the access to full information of the infection's real scenery, whereas others like Austria, Belgium, Italy and etc. applied new technologies in response to COVID-19 outbreak to save lives (COVID News, 2020).

According to the Electronic Frontier Foundation of Canada (McPail, 2020) has identified some basic principles to track people concerning COVID-19, which includes measures like interference with the privacy must be necessary and 
proportionate to the risks, data collection must be unbiased, and scientifically approved, collection, usage, maintenance, processing, and explanations about the ways of information will be used must be transparent, creating accessibility of persons to challenge decisions made about them using their private data, and being ensured that the measures are not permanent after the pandemic is past.

\subsection{Effective Functionality of Justice System}

Besides, the effectiveness of judiciary is necessary during public health emergencies as a guarantee of rule of law and protection of rights. The prompt decisions given by courts are essential in terms of prevention the possible threats posed to the general public health; therefore, it is significantly important to be legally prepared to avoid any public health actions aimed at unduly interfere with civil rights. Wide outbreak of severe infections may create unprecedented problems to courts.

Due to outbreak of contagious diseases thousands of people are locked in quarantine, isolation or be subjected to "social distancing" measures as it happened during SARS and COVID-19 pandemics. But, public officials may involuntarily or forcibly exercise civil confinement of persons. In this circumstance, courts must be ensured that amid enforcing these protective measures, civil rights are not breached. At least, courts should attain to do due process protections, including adequate written notice of the grounds and underlying the facts, access to a lawyer, right to be appear before the court and participate all stages of court hearings, a standard of proof and access to the transcript to appeal (Greene v. Edwards. 263 S.E. 2d 661, 1980).

In the globalized and interlinked world, today everything is digital and automatized. Preferring "face-to-face" traditional court hearings to cyber courts, the governments have taken precautionary measures to response COVID-19 in order to fully realize the right to stand trial or due diligence and to speed up the process through intelligent using of communication technologies. As the so-called "Godfather of the legal tech" Richard Susskind says the future of the law will be based on intelligent technology. For example, in one of the cyber courts in China, AI-judges and evidences were exchanged through apps to accelerate the legal process (Legal Tech Weekly, 2020).

Cyber courts have its own pros and cons. From one hand, online procedures speed the procedures, and ease the overload of judges, transactions of the cases previously take days can now completed online in seconds. Furthermore, bureaucratic formalities in processing of decisions slow down the process of course, some of such delays are justifiable due to the plenty of legal rules and 
norms that should be analyzed in order to take just and reasonable decision for both parties to the case. This will also good practice for other lawyers and prosecutors dealing with the case but based in other cities to participate in the court proceedings transferred to the higher instant court via audio, video or internet conferencing. For the other hand, it will need time and costs for programming and building such courts and there is a risk of closures of the court rooms, which will lead to undue delays of the cases pending.

In overall, the feeling of being in virtual courts is good in terms of easing and speeding the court proceedings, however, human factor, eye-contact with witness and judges, real emotions during testimony or cross-examinations that experienced in traditional courts also have their own advantages.

\section{Conclusion}

Summing up, we studied that states must ensure non-discrimination principle, freedom from degrading treatment and torture, respect for human dignity not only peace, but also in emergencies, although there were substantive principles for derogation of states from the rights.

As anticipated, the states took all precautionary measures in order to avoid all possible complications, death toll, economic reduce and etc. eventually, the governments totally lockdown their national borders, or reducing their international and internal flights, and transportations to minimum. Nevertheless, some of those emergency measures can be illegitimate or disproportionate to the threats posed.

States should consider the rights of all persons under their jurisdiction and respect to privacy and ensure confidentiality of those seeking healthcare, whistleblowers, and those, who cooperate during the investigation procedure. As well as it is important to inform the public with accurate information about symptoms, causes, possible duration, rate of the confirmed, recovered and deaths toll, taken protective measures and etcetera on a regular basis in order to avoid misinformation among society. It would be advisable to educate the society to abstain from negative behaviors, including spreading misinformation about the infection as well as smearing any individual, groups of people or particular community members on social network. 
Likewise, the authorities should refrain detaining persons, who spread misinformation instead of raising their awareness about the negative consequences of such misconducts in the society. This and refrain from detaining them. As well as to give the opportunity to detained persons to contact with the relatives and friends in the pandemic or natural disaster affected region.

The governments must alert and ensure the people not to discriminate against and stigmatize anyone with humiliating messages, statements and hate speech either in news or social media. States must not repeat each specific preventive and control measures in response to pandemic as it depends on economic situation and timely emergency preparedness. Contrary, each state should have its own emergency preparedness plan considering its ups and downs.

According to our work, we concluded that despite fact that governments take precautionary measures to cease the infection, support each-other, and remand those who shared misinformation on social media. But almost all states copy and paste each-other's experience how to prevent and control the pandemic. We argue that budget and development rate have to be taken into account whilst enforcing some international experiences, particularly transformation from courtrooms into virtual judicial procedures as it may sometimes cause to undue delays of trials and interim measures as well as to languish of trial records. As a result of our studies, we revealed that amid the pandemic, some people, including healthcare professionals may be stigmatized and became victims of the disease, as it happened in the US with the health professionals, who were infected as a result of lack of medical equipment, and because they were forced to wear bin bags. And therefore, taking into account all possible negative forecasts during emergencies, states must be prepared for everything in advance. As a result of literature review, it can be seen that the situation, dealing with people, who are neither migrants, nor persons seeking for refuge nor homeless, but temporarily residing persons, including students, persons traveling for business or just those who crossing the national borders of one particular country to go home as well as different family situations with double citizenship delayed at customs for a long time have not been considered thoroughly. Likewise, what kind of interim or urgent measures must be taken by host country territory remained open ended. It is also suggested that the studies should be carried out in the direction of future trends in the field of justice and emergency and training of medical staff in prisons and residential institutions, including authorities' mutual cooperation with the staff in those facilities. 


\section{Disclosure statement}

No potential conflict of interest was reported by the authors.

Contact Information.

Email address: sevinjsener@ gmail.com 


\section{References and notes:}

Advice of the UN Subcommittee on Prevention of Torture. (25 March 2020). Advice of the Subcommittee on Prevention of Torture to States Parties and National Preventive Mechanisms relating to the Coronavirus Pandemic

African Charter on Human and Peoples' Rights (1981), Article 9. OAU CAB/LEG/67/3rev.5; 1520 UNTS 217; 21 ILM 58 (1982).

American Convention on Human Rights. (1969). 1144 UNTS 123 (ACHR). Article 13.

Centers for Disease Control and Prevention (CDC). (2020). Reducing Stigma. 18 April 2020. Retrieved from https://www.cdc.gov/coronavirus/2019-ncov/daily-lifecoping/reducing-stigma.html

Constitution of the World Health Constitution. (1946)

COVID-19. (2020). Surveillance and the threat to your rights. 3 April 2020. Retrieved from https://www.amnesty.org/en/latest/news/2020/04/covid-19-surveillance-threat-toyour-rights/

European Convention on Human Rights and Fundamental Freedoms. ( 1950). ETS 5 (ECHR). Articles 10 and 15

Fottrell Q. (13 April 2020). Nurses are wearing garbage bags as they battle coronavirus: It's like something out of the Twilight Zone". MarketWatch.com. 21 April 2020. Retrieved from:https://www.marketwatch.com/story/nurse-at-brooklyn-hospital-oncoronavirus-protective-clothing-its-a-garbage-bag-its-like-something-out-of-thetwlight-zone-2020-04-07

Freeman H.E. (2005). Cybercourts and the future of justice. 18 April 2020. Retrieved from doi: 10.1201/1086/45098.14.1.20050301/87266.2. Information Systems Security (2005 March/April). 1-9

Greene v. Edwards. 263 S.E. 2d 661 (1980). Retrieved 15 April 2020 from https://www.courtlistener.com/opinion/1323449/greene-v-edwards/

Hartman F J.(1985) Working Paper for the Committee of Experts on the Article 4 Derogation provision (7 Hum. Rts. Q. 89, 91)

Human Rights Committee. General Comment 29, States of Emergency. (2001). (article 4). [U.N. Doc. CCPR/C/21/Rev.1/Add.11]. para.17

Human Rights Watch Report. (14 April 2020). Covid-19: Human Rights Checklist. 15 April 2020. Retrieved from https://www.hrw.org/news/2020/04/14/covid-19-humanrights-checklist

Human Rights Watch (23 April 2020). Sri Lanka Due Process Concerns in Arrests of Muslims. [Online Article.] 23 April 2020. Retrieved from https://www.hrw.org/news/2020/04/23/sri-lanka-due-process-concerns-arrestsmuslims. See also https://www.cpalanka.org/disposal-of-bodies-of-deceasedpersons-who-were-infected-with-and-suspected-of-being-infected-with-covid-19/

International Covenant on Civil and Political Rights. (1966) 999 UNTS 171 (ICCPR). Article 19.

International Covenant on Economic, Social and Cultural Rights. (1966). Article 12

International Labor Organization Convention on Occupational Accidents and Disease. (1985). No.161. Article 5.

Leander v Sweden. (26 March 1987). 9 EHRR 433.

LegalTechWeekly. (2020). Are online courts the future of justice? 15 April 2020. Retrieved from https://suits.contractbook.com/legaltechweekly/are-online-courts-the-future-ofjustice

McDonald M. (2013). The Right to information in international human rights law. In Human Rights Law Review 13:1(2013), pp.25-55, p.30

McPail B. (19 March 2020). Public health, pandemics and privacy. Canadian Civil Liberties Association. 3 April 2020. Retrieved from https://ccla.org/coronavirus-updateprivacy/ 
Nazia P.(5 April 2020). Police investigate UK far-right groups over anti-Muslim coronavirus claims. [Online Article]. 8 April 2020. Retrieved from https://www.theguardian.com/world/2020/apr/05/police-investigate-uk-far-rightgroups-over-anti-muslim-coronavirus-claims

OHCHR. (19 March 2020). COVID-19: Governments must promote and protect access to and free flow of information during pandemic - International experts. 21 April 2020. Retrieved from: https://www.ohchr.org/EN/NewsEvents/Pages/DisplayNews.aspx?NewsID=25729\&LangID $=$ Eccess

Ortega N. (14 April 2020).Free expression, hunger and racism in context of COVID-19. [Online Article]. 21 April 2020. Retrieved from https://groundviews.org/2020/04/14/freeexpression-hunger-and-racism-in-context-of-covid19/

Perrigo B. (3 April 2020), It was already dangerous to be Muslim in India. Then came the Coronavirus, [Online article]. 15 April 2020. Retrieved from https://time.com/5815264/coronavirus-india-islamophobia-coronajihad/

Segerstedt-Wiberg v Sweden (2006). VII; 44 EHRR 2

Sheinin M. (2002). State responsibility, good governance and indivisible human rights. In HansOtto-Sano. Gudmundur Alfredson. Robin Clapp. (Ed). Human Rights and Good Governance. Building Bridges. Brill \& Nijhoff Publishers, pp. 27-44. P. 27 (in Azeri version)

UN Commission on Human Rights/The Siracusa Principles on the Limitation and Derogation Provisions in the International Covenant on Civil and Political Rights. (28 September 1984). [E/CN.4/1985/4]. para 25. 10 March 2020. Retrieved from https://www.refworld.org/docid/4672bc122.html

Universal Declaration of Human Rights (1948)

UN Human Rights Committee (HRC). CCPR General Comment No. 27: Article 12 (Freedom of Movement). (2 November 1999). [CCPR/C/21/Rev.1/Add.9]

UN Human Rights Committee (HRC). CCPR General Comment No. 29: Article 4: Derogations during a State of Emergency.(31 August 2001). [CCPR/C/21/Rev.1/Add.11]

UN Human Rights experts Statement on COVID-19. 20 March 2020. Retrieved from https://www.ohchr.org/EN/NewsEvents/Pages/DisplayNews.aspx?NewsID=25722

United Nations International Covenant on Civil and Political Rights. (1966). Article 4

Vienna Declaration and Programme of Action. (14-25 June 1993). [A/CONF.157/23], para 5, World Conference on Human Rights

World Health Organization. (2003).Severe Acute Respiratory Syndrome (SARS)

World Health Organization Interim Guidance.(24 March 2020). Infection Prevention and Control for the safe management of a dead body in the context of COVID-19. [Paper.] 30 March 2020. Retrieved from https://apps.who.int/iris/bitstream/handle/10665/331538/WHO-COVID-191PC_DBMgmt-2020.1-eng.pdf

WTO. National International Health Regulations (2005) (IHR).10 March 2020. Retrieved from https://www.who.int/healthsystems/topics/health-law/chapter11.pdf 